\title{
PENGARUH MODEL PEMBELAJARAN BERDASARKAN MASALAH TERHADAP HASIL BELAJAR SISWA PADA MATERI POKOK KINEMATIKA GERAK LURUS DI SMA NEGERI 1 TANJUNG MORAWA T.P. 2015/ 2016
}

\author{
Henok Siagian dan Rizal Yosua Manurung \\ Jurusan Fisika FMIPA Universitas Negeri Medan \\ Jalan Willem Iskandar Pasar V Medan, Sumatera Utara \\ manurungrizal50@yahoo.com
}

\begin{abstract}
ABSTRAK
Penelitian ini bertujuan untuk mengetahui pengaruh model pembelajaran berdasarkan masalah terhadap hasil belajar siswa pada materi pokok kinematika gerak lurus di kelas X SMA Negeri 1 Tanjung Morawa T.P. 2015/2016. Jenis penelitian ini adalah quasi experiment dengan populasi seluruh siswa kelas X SMA Negeri 1 Tanjung Morawa T.P. 2015/2016 yang terdiri dari 10 kelas. Pengambilan sampel dilakukan dengan cara cluster random sampling dengan mengambil 2 kelas yaitu kelas X-9 sebagai kelas eksperimen dan kelas X-10 sebagai kelas kontrol. Instrumen yang digunakan adalah tes hasil belajar berbentuk essay test dengan jumlah 9 soal dan lembar observasi untuk mengamati aktivitas siswa. Hasil penelitian diperoleh nilai rata-rata pretes kelas eksperimen 15,88 dan kelas kontrol 14,91. Berdasarkan uji normalitas dan uji homogenitas diperoleh bahwa data pretes kedua kelas sampel normal dan homogen. Setelah diberi perlakuan berbeda, yaitu model pembelajaran berdasarkan masalah pada kelas eksperimen dan pembelajaran konvensional pada kelas kontrol maka diperoleh nilai rata-rata postes kelas eksperimen 63,85 dan kelas kontrol 53,55. Hasil observasi menunjukkan bahwa aktivitas kelas eksperimen meningkat setiap pertemuan, dengan nilai rata-rata masing-masing secara berurut adalah 60, 66 dan 73. Hasil uji hipotesis diperoleh bahwa ada pengaruh model pembelajaran berdasarkan masalah terhadap hasil belajar siswa pada materi pokok kinematika gerak lurus di kelas $\mathrm{X}$ semester I SMA Negeri 1 Tanjung Morawa T.P. 2015/2016.
\end{abstract}

Kata kunci: model pembelajaran berdasarkan masalah, hasil belajar, aktivitas.

\begin{abstract}
This research aimed to know the effect of problem based learning model on students' learning outcomes in the subject matter linear kinematics in class X SMA Negeri 1 Tanjung Morawa A.Y.2015/2016. The type of research was quasi-experimental with the population were the tenth grade students of SMA Negeri 1 Tanjung A.Y. 2014/2015 consisting of 10 classes. Samples were taken 2 classes determined by cluster random sampling technique, the class X-9 as experiment class and class X-10 as control class. The instruments used in the form of essay as much as 9 questions. The research result shows the pretest's average score of experiment class is 15,88 and control class is 14,91. From normality test and homogenity test obtained that pretest of experiment class and
\end{abstract}


control class is normal and homogen. After they have been given different treatment, problem based learning model for experimental class and conventional learning model for controlling class it is obtained that the posttest's average score for experiment class is 63,85 and controlling class's is 53,55. Observations indicate that the activity student experiment class is increasing every meeting, with the average value of each respectively are 60, 66 and 73. The hypothesis there is effect of problem based learning model in the subject matter linear kinematics in class X SMA Negeri 1 Tanjung Morawa A.Y. $2015 / 2016$.

Keywords: Problem based learning model,learning outcome, activity.

\section{PENDAHULUAN}

Pendidikan sebagai salah satu sektor utama dalam pembangunan nasional karena dapat difungsikan semaksimal mungkin dalam meningkatkan kualitas hidup umat manusia. Seiring dengan semakin berkembangnya ilmu pengetahuan dan teknologi, dituntut untuk mampu bersaing dan sejajar dengan bangsa-bangsa lain.

Seiring dengan perkembangan zaman, fisika memiliki peran dalam mengembangkan ilmu pengetahuan dan teknologi. Fisika dianggap penting untuk diajarkan sebagai mata pelajaran terintegrasi karena selain memberikan bekal ilmu pengetahuan kepada peserta didik, fisika dapat digunakan sebagai wahana dalam menumbuhkan kemampuan pemecahan masalah dalam kehidupan sehari-hari. Lemahnya minat dan keaktifan siswa dalam belajar menjadi permasalahan utama dalam proses pembelajaran sebagai interaksi antara guru dengan siswa.

Fisika adalah cabang ilmu pengetahuan alam yang mempelajari fenomena dan gejala alam secara empiris, logis, sistematis dan rasional yang melibatkan proses dan sikap ilmiah. Fisika merupakan salah satu pelajaran yang cukup menarik karena langsung berkaitan dengan kejadian yang nyata dan juga dapat diaplikasikan dalam teknologi kehidupan sehari-hari. Kenyataannya, pelajaran fisika hingga saat ini masih dianggap sebagai pelajaran yang sulit dipahami.
Hal ini terbukti dari hasil studi pendahuluan yang dilakukan di kelas $\mathrm{X}$ SMA Negeri 1 Tanjung Morawa dengan menyebarkan angket. Berdasarkan hasil angket diperoleh informasi bahwa $48 \%$ dari 33 siswa menyatakan pelajaran fisika sebagai mata pelajaran yang sulit, $52 \%$ mengatakan pelajaran fisika sebagai mata pelajaran yang biasa dan $75 \%$ mengatakan bahwa pelajaran fisika sebagai mata pelajaran yang membosankan. Pembelajaran selama ini hanya menuntut siswa untuk menguasai materi dan menghafal rumus-rumus untuk memecahkan suatu masalah tanpa mengetahui konsep dan aplikasinya dalam kehidupan sehari-hari. Siswa hanya bisa menulis dan mencatat apa yang didengar dan dijelaskan oleh guru, tanpa pernah terlibat langsung dalam proses menemukan pengetahuan atau pun mengembangkan pengetahuan sesuai dengan kemampuannya sendiri.

Berdasarkan hasil wawancara dengan salah seorang guru fisika di SMA Negeri 1 Tanjung Morawa, diperoleh informasi bahwa respon siswa terhadap mata pelajaran fisika masih rendah. Hal ini dapat dilihat

bahwa selama proses pembelajaran hanya beberapa siswa yang aktif bertanya atau mengemukakan pendapat. Model pembelajaran yang diterapkan di dalam kelas masih pembelajaran konvensional dengan metode ceramah dan tanya jawab. 
Dampaknya, hasil belajar siswa masih kurang dari KKM. Nilai rata-rata hasil belajar siswa hanya mencapai 65 untuk standar KKM mata pelajaran fisika sebesar 70 .

Berdasarkan kenyataan tersebut, perlu diterapkan suatu pembelajaran yang membuat siswa lebih berperan aktif dalam keseluruhan proses pembelajaran dengan mengangkat masalah-masalah melalui fenomena fisika yang lebih autentik dalam kehidupan sehari-hari. Peningkatan hasil belajar siswa didukung oleh penggunaan model pembelajaran yang bervariasi. Salah satu model yang digunakan dalam penelitian ini adalah model pembelajaran berdasarkan masalah.

Model pembelajaran berdasarkan masalah adalah suatu pendekatan pembelajaran dimana siswa mengerjakan masalah yang autentik dengan maksud untuk menyusun pengetahuan mereka sendiri serta dapat mengembangkan kemandirian dan rasa percaya diri (Arends, 2012:384). Pembelajaran berdasarkan masalah merupakan pembelajaran yang berangkat dari sebuah kasus tertentu yang kemudian akan dianalisis untuk menemukan pemecahan masalahnya. Selain itu model pembelajaran berdasarkan masalah dapat menumbuhkan keterampilan siswa untuk membangun suatu pemecahan masalah yang kompleks (Santyasa, 2007:173).

Penelitian terkait tentang model pembelajaran berdasarkan masalah telah dilakukan oleh Sembiring (2014:53) diperoleh rata-rata hasil belajar siswa di kelas eksperimen sebesar 40,94, sedangkan kelas kontrol sebesar 27,50. Artinya Ada perbedaan hasil belajar siswa menggunakan model pembelajaran berdasarkan masalah dengan menggunakan pembelajaran konvensional. Selanjutnya, Simarmata (2015:66) dengan hasil penelitian menyimpulkan bahwa pembelajaran fisika dengan menerapkan model pembelajaran berdasarkan masalah dapat meningkatkan hasil belajar siswa dan terjadi peningkatan aktivitas setiap pertemuan dengan nilai rata- rata siklus I sebesar 60,35, siklus II sebesar 68,28 dan siklus III sebesar 77,38. Siregar (2015:58) menyimpulkan ada peningkatan hasil belajar belajar dari rata-rata 64,38 menjadi 75,94 serta peningkatan aktivitas belajar pada pertemuan I sebesar $55 \%$, pertemuan II sebesar $72 \%$, dan pertemuan III sebesar $74 \%$. Artinya Pembelajaran fisika dengan menerapkan model pembelajaran berdasarkan masalah dapat meningkatkan aktivitas dan hasil belajar siswa dalam pembelajaran fisika. Ketiga penelitian ini memperlihatkan bahwa ada pengaruh model pembelajaran berdasarkan masalah terhadap hasil belajar siswa.

Penelitian ini masih mengalami beberapa kendala antara lain kurang terlibatnya siswa pada saat proses pembelajaran berlangsung hingga menyebabkan sulitnya mengatur alokasi waktu serta kurangnya penalaran siswa dalam menemukan masalah dalam kelompok sehingga suasana belajar mengajar kurang kondusif. Peneliti ingin mengkondusifkan kelas dengan memfasilitasi siswa dengan bahan ajar serta sistem pembagian LKS per individu siswa.

Berdasarkan penelitian di atas, maka peneliti berkeinginan melakukan penelitian dengan tujuan untuk mengetahui pengaruh model pembelajaran berdasarkan masalah terhadap hasil belajar siswa pada materi pokok kinematika gerak luus di kelas $\mathrm{X}$ semester I SMA Negeri 1 Tanjung Morawa T.P. 2015/2016.

\section{METODE PENELITIAN}

Populasi dalam penelitian ini adalah seluruh siswa kelas $X$ SMA Negeri 1 Tanjung Morawa T.P. 2015/2016 yang terdiri dari 10 kelas dengan jumlah siswa 350 orang. Sampel dalam penelitian ini terdiri dari dua kelas yang dipilih dengan cara cluster random sampling yaitu kelas X-9 sebagai kelas eksperimen (kelas yang diajar menggunakan model pembelajaran berdasarkan masalah) dengan jumlah 33 siswa dan kelas X-10 sebagai kelas kontrol (kelas yang diajar menggunakan pembelajaran konvensional) dengan jumlah 
33 siswa. Penelitian ini termasuk jenis penelitian quasi experiment yaitu merupakan penelitian yang dimaksudkan untuk mengetahui ada atau tidaknya akibat dari sesuatu yang dikenakan pada subjek yaitu siswa. Desain penelitian yang digunakan adalah control group pre testpost test design yang ditunjukkan pada Tabel 1.

Tabel 1. Control Group Pretest-Posttest

\begin{tabular}{|l|c|c|c|}
\multicolumn{1}{|c|}{ Delas } & Pretes & $\begin{array}{c}\text { Perla } \\
\text { kuan }\end{array}$ & Postes \\
\hline Eksperimen & $O_{1}$ & $X_{1}$ & $O_{2}$ \\
\hline Kontrol & $O_{1}$ & $X_{2}$ & $O_{2}$ \\
\hline
\end{tabular}

Sumber: Sugiyono, 2011

Keterangan:

$O_{1}=$ pretes

$X_{1}=$ model problem based learning

$\mathrm{O}_{2}=$ postes

$X_{2}=$ pembelajaran konvensional

Instrumen penelitian ini adalah tes hasil belajar berberntuk tes essay dengan jumlah 9 item yang sudah divalidasikan oleh dua orang dosen jurusan fisika di Unimed dan seorang guru fisika di SMA Negeri 1 Tanjung Morawa. Hasil dari validitas isi menyatakan bahwa soal dikatakan valid dengan kriteria penilaian amat baik dan empat soal perlu diperbaiki kalimat indikatornya.

Sebelum dilakukan penganalisisan data, terlebih dahulu ditentukan skor masing-masing kelompok sampel lalu dilakukan pengolahan data dengan langkahlangkah sebagai berikut:

a) Menghitung nilai rata-rata dan simpangan baku

b) Uji normalitas dengan menggunakan uji lilliefors

c) Uji homogenitas dengan menggunakan uji kesamaan dua varians Uji normalitas dan uji homogenitas dimaksudkan sebagai prasyarat melakukan uji hipotesis jika populasi terdistribusi normal dan homogen.

d) Pengujian hipotesis dengan menggunakan uji $\mathrm{t}$
Uji hipotesis dua pihak dengan menggunakan uji $\mathrm{t}$ (uji beda) untuk mengetahui kesamaan kemampuan awal siswa pada kedua kelompok sampel dan uji hipotesis satu pihak dengan menggunakan uji $t$ untuk mengetahui pengaruh dari suatu perlakuan yaitu model pembelajaran berdasarkan masalah terhadap hasil belajar siswa.

\section{HASIL DAN PEMBAHASAN Hasil Penelitian}

Data pretes kelas eksperimen dan kontrol ditunjukkan pada Tabel 2.

Tabel 2. Data Pretes Kelas Eksperimen dan Kontrol

\begin{tabular}{|c|c|c|c|c|c|c|c|}
\hline \multicolumn{4}{|c|}{ Pre-tes kelas eksperimen } & \multicolumn{4}{|c|}{ Pre-tes kelas control } \\
\hline $\begin{array}{l}\mathrm{N} \\
\mathrm{O}\end{array}$ & Nilai & $F$ & & $\begin{array}{l}\mathrm{N} \\
\mathrm{O}\end{array}$ & Nilai & $f$ & \\
\hline 1 & $8-10$ & 2 & \multirow{7}{*}{$\begin{array}{l}15 \\
88\end{array}$} & 1 & $8-10$ & 4 & \multirow{7}{*}{14,9} \\
\hline 2 & $11-13$ & 8 & & 2 & $11-13$ & $\begin{array}{l}1 \\
1\end{array}$ & \\
\hline 3 & $14-16$ & $\begin{array}{l}1 \\
0\end{array}$ & & 3 & $14-16$ & 7 & \\
\hline 4 & $17-19$ & 9 & & 4 & $17-19$ & 5 & \\
\hline 5 & $20-22$ & 2 & & 5 & $20-22$ & 5 & \\
\hline 6 & $23-25$ & 0 & & 6 & $23-25$ & 1 & \\
\hline 7 & $26-28$ & 2 & & 7 & $26-28$ & 0 & \\
\hline & umlah & $\begin{array}{l}3 \\
3\end{array}$ & & \multicolumn{2}{|c|}{ Jumlah } & $\begin{array}{l}3 \\
3\end{array}$ & \\
\hline
\end{tabular}

Berdasarkan Tabel 2, pembahasan nilai pretes kelas eksperimen dan kelas kontrol dapat dilihat pada Gambar 1 .

Gambar 1. Diagram nilai pretes kelas eksperimen dan kelas kontrol

Hasil uji normalitas data pretes masing-masing pada kelas eksperimen diperoleh $\mathrm{L}_{\text {hitung }}=0,1209<\mathrm{L}_{\text {tabel }}=0,1542$ dan kelas kontrol diperoleh $\mathrm{L}_{\text {hitung }}=0,1389$ $<\mathrm{L}_{\text {tabel }}=0,1542$. Hasil uji homogenitas pada data pretes diperoleh $\mathrm{F}_{\text {hitung }}=1,1787<$ $\mathrm{F}_{\text {tabel }}=1,8080$. Berdasarkan hasil kedua pengujian ini disimpulkan bahwa populasi berdistribusi normal dan homogen sehingga layak dilakukan uji hipotesis dua pihak 
dengan hasil uji hipotesis seperti pada Tabel 3 .

Tabel 3. Uji Hipotesis Data Pretes

\begin{tabular}{|l|l|c|c|}
\hline \multicolumn{1}{|c|}{$\begin{array}{c}\text { Data } \\
\text { Pretes }\end{array}$} & $\begin{array}{l}\text { Rata- } \\
\text { rata }\end{array}$ & $\mathrm{t}_{\text {hitung }}$ & $\mathrm{t}_{\text {tabel }}$ \\
\cline { 1 - 2 } $\begin{array}{l}\text { Kelas } \\
\text { Eksperime } \\
\mathrm{n}\end{array}$ & 15,88 & $\begin{array}{c}0,950 \\
9\end{array}$ & 1,9987 \\
\cline { 1 - 2 } $\begin{array}{l}\text { Kelas } \\
\text { Kontrol }\end{array}$ & 14,91 & & \\
\hline
\end{tabular}

Diperoleh bahwa untuk nilai pretes untuk $\alpha=0,05$ yaitu $\mathrm{t}_{\text {hitung }}=0,9509, \mathrm{t}_{\text {tabel }}=$ $1,9987 \quad\left(t_{\text {hitung }}>t_{\text {tabel }}\right)$. Hal ini dapat disimpulkan bahwa kemampuan awal kedua kelas sama. Setelah selesai proses pembelajaran dimana pada kelas eksperimen digunakan model pembelajaran berdasarkan masalah sedangkan pada kelas kontrol menggunakan pembelajaran konvensional, maka dilakukan postes untuk mengetahui ada tidaknya perbedaan antara pretes dan postes. Nilai rata-rata postes untuk kelas eksperimen dan kontrol ditunjukkan pada tabel 4 .

Tabel 4. Data Postes Kelas Eksperimen dan Kontrol

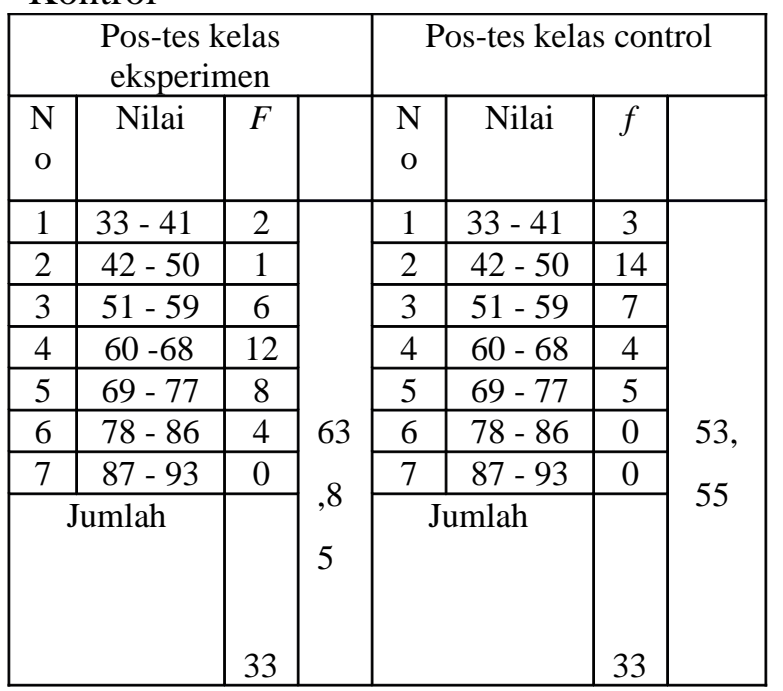

Penjelasan lebih lanjut berdasarkan tabel 4, mengenai pembahasan nilai postes kelas eksperimen dan kelas kontrol dapat dilihat pada gambar 2 .
Gambar 2. Diagram nilai postes kelas eksperimen dan kelas kontrol

Hasil uji normalitas data postes masing-masing pada kelas eksperimen diperoleh $\mathrm{L}_{\text {hitung }}=0,0790<\mathrm{L}_{\text {tabel }}=0,1542$ dan kelas kontrol diperoleh $\mathrm{L}_{\text {hitung }}=0,1483$ $<\mathrm{L}_{\text {tabel }}=0,1542$. Hasil uji homogenitas pada data pretes diperoleh $\mathrm{F}_{\text {hitung }}=1,2317<$ $F_{\text {tabel }}=1,8080$. Untuk mengetahui pengaruh model pembelajaran terhadap hasil belajar maka dilakukan uji hipotesis satu pihak dengan hasil uji hipotesis seperti pada Tabel 5.

Tabel 5. Uji Hipotesis Data Postes

\begin{tabular}{|l|c|c|c|}
\hline \multicolumn{1}{|c|}{$\begin{array}{c}\text { Data } \\
\text { Pretes }\end{array}$} & $\begin{array}{l}\text { Rata- } \\
\text { rata }\end{array}$ & $\mathrm{t}_{\text {hitung }}$ & $\mathrm{t}_{\text {tabel }}$ \\
\cline { 1 - 2 } $\begin{array}{l}\text { Kelas } \\
\text { Eksperime } \\
\mathrm{n}\end{array}$ & 15,88 & $\begin{array}{c}3,814 \\
8\end{array}$ & 1,6693 \\
\cline { 1 - 2 } $\begin{array}{l}\text { Kelas } \\
\text { Kontrol }\end{array}$ & 14,91 & & \\
\hline
\end{tabular}

Diperoleh bahwa untuk nilai postes untuk $\alpha=0,05$ yaitu $t_{\text {hitung }}=3,8148, t_{\text {tabel }}=$ 1,6693 ( $\left.\mathrm{t}_{\text {hitung }}>\mathrm{t}_{\text {tabel }}\right)$. Hal ini dapat disimpulkan bahwa ada pengaruh pembelajaran berdasarkan masalah terhadap hasil belajar siswa pada materi pokok kinematika gerak lurus di kelas X semester I SMA Negeri 1 Tanjung Morawa T.P. 2015/2016.

Selama proses pembelajaran, pengamatan aktivitas siswa dilakukan selama tiga kali pertemuan setelah melakukan pretes. Observasi aktivitas ini dilakukan di kelas eksperimen yang sesuai dengan penerapan model pembelajaran yang digunakan. Aspek aktivitas yang dinilai adalah merumuskan hipotesis, melakukan diskusi, melakukan percobaan, memecahkan masalah dan mempresentasikan hasil karya. Rata-rata aktivitas siswa kelas eksperimen ditunjukkan pada Gambar 3.

Gambar 3. Diagram batang aktivitas 
Berdsarkan gambar 3, Aktivitas siswa kelas eksperimen meningkat di setiap pertemuan. Kelas kontrol tidak memiliki penilaian aktivitas karena aktivitas pada kelas kontrol tidak cocok dengan kelima aspek penilaian aktivitas tersebut. Hal ini disebabkan karena pada kelas kontrol, guru yang lebih berperan aktif daripada siswa. Siswa hanya mendengarkan, mencatat dan mengerjakan soal yang diberikan oleh guru.

Selama kegiatan pembelajaran dalam tiga pertemuan dibagikan juga LKS kepada setiap siswa untuk mengaktifkan kegiatan per individu dalam kelas dalam mencapai indikator aktivitas dan psikomotor yang lebih maksimal. Hasil LKS yang dibagikan kepada siswa pada pertemuan I diperoleh nilai rata-rata 67,58 , pada pertemuan II diperoleh nilai rata-rata 71,52 dan pada pertemuan III diperoleh nilai rata-rata 67,58 .

Data penelitian di atas dapat lebih dispesifikasikan lagi dalam kategorikategori berikut: siswa yang memiliki kriteria pretes sangat kurang, kriteria aktivitas sangat aktif dan kriteria postes sangat baik berjumlah 1 siswa; kriteria pretes sangat kurang, kriteria aktivitas sangat aktif dan kriteria postes baik berjumlah 4 siswa; siswa yang memiliki kriteria pretes sangat kurang, kriteria aktivitas sangat aktif dan kriteria postes cukup berjumlah 4 siswa; siswa yang memiliki kriteria pretes sangat kurang, kriteria aktif dan kriteria postes kurang berjumlah 1 siswa; siswa yang memiliki kriteria pretes sangat kurang, kriteria aktivitas sangat aktif dan kriteria postes sangat kurang berjumlah 1 siswa; siswa yang memiliki kriteria pretes sangat kurang, kriteria aktivitas aktif dan kriteria postes baik berjumlah 3 siswa; siswa yang memiliki kriteria pretes sangat kurang, kriteria aktivitas aktif dan criteria postes cukup baik berjumlah 4 siswa; serta siswa yang memiliki kriteria pretes sangat kurang, kriteria aktivitas aktif dan criteria postes kurang berjumlah 3 siswa; serta siswa yang memiliki kriteria pretes sangat kurang, kriteria aktivitas aktif dan kriteria postes sangat kurang berjumlah 1 siswa; siswa yang memiliki kriteria pretes sangat kurang, kriteria aktivitas cukup aktif dan kriteria postes baik berjumlah 3 siswa; siswa yang memiliki kriteria pretes sangat kurang, kriteria aktivitas cukup aktif dan kriteria postes cukup baik berjumlah 4 siswa; siswa yang memiliki kriteria pretes sangat kurang, kriteria aktivitas cukup aktif dan kriteria postes kurang berjumlah 2 siswa; siswa yang memiliki kriteria pretes sangat kurang, kriteria aktivitas cukup aktif dan kriteria postes sangat kurang berjumlah 1 siswa, serta siswa yang memiliki kriteria pretes sangat kurang, kriteria aktivitas kurang aktif dan kriteria postes cukup baik berjumlah 1 siswa.

\section{Pembahasan}

Nilai rata-rata pretes siswa di kelas kontrol sebesar 15,88 dan nilai rata-rata postes sebesar 14,91 sedangkan di kelas eksperimen nilai rata-rata pretesnya 63,58 dan nilai rata-rata postesnya 53,55. Hasil penelitian uji hipotesis menggunakan uji $\mathrm{t}$ (uji beda) menunjukkan bahwa ada pengaruh model pembelajaran berdasarkan masalah terhadap hasil belajar siswa pada materi pokok kinematika gerak lurus di Kelas X Semester I SMA Negeri 1 Tanjung Morawa.

Siswa yang mampu mencapai KKM di kelas eksperimen hanya 33,3\% dengan nilai terendah 33 dan nilai tertinggi 85 , sementara di kelas kontrol siswa yang mampu mencapai KKM yaitu 6\% dengan nilai terendah 39 dan nilai tertinggi 71 . Hal ini dipengaruhi oleh taraf kesukaran soal. Soal yang diberikan kepada siswa memiliki taraf kesukaran dengan kategori sedang dan sukar. Soal yang diberikan kepada siswa lebih banyak dengan kategori sukar berupa C4, C5 dan C6 sehingga mempengaruhi hasil belajar siswa. Meskipun demikian, hasil belajar siswa dengan menggunakan model pembelajaran berdasarkan masalah memberikan pengaruh dengan peningkatan hasil belajar sebesar 47,97\% .

Sanjaya (2011:217) menyatakan bahwa model pembelajaran berdasarkan 
masalah merupakan rangkaian aktivitas pembelajaran yang menekankan kepada proses penyelesaian masalah yang dihadapi secara ilmiah. Pemberian masalah dilakukan melalui dialog antara guru dan siswa dalam memecahkan masalah sesuai masalah yang tertera dalam LKS. Hasil penilaian LKS diperoleh bahwa terjadi peningkatan pada setiap pertemuan. Aktivitas pengerjaan LKS dapat memberikan pengaruh terhadap nilai postes siswa kelas eksperimen, karena pada saat pengerjaan LKS siswa dilatih kemampuan pemecahan masalah terhadap masalah di kehidupan sehari-hari yang berkaitan dengan materi kinematika gerak lurus sehingga siswa dapat mengerjakan soal tes hasil belajar. Selain itu sistem pembagian LKS per individu dapat mendorong siswa lebih mandiri dalam mengeluarkan pendapat dan pertanyaan tanpa ada keraguan akan jawaban salah.

Penelitian yang dilakukan peneliti dengan menggunakan model pembelajaran berdasarkan masalah dalam pembelajaran cukup menarik perhatian siswa, sehingga siswa lebih antusias mengikuti pembelajaran. Penggunaan model pembelajaran berdasarkan masalah membuat siswa merasa diikutsertakan dalam pembelajaran. Siswa menjadi tahu bahwa masalah dalam kehidupan seharihari dapat diselesaikan dengan cara tertentu. Siswa senang karena mereka diberikan kesempatan untuk melakukan penyelidikan sendiri melalui eksperimen dimana sebelumnya sama sekali belum pernah dilakukan baik di dalam kelas maupun di laboratorium.

Rasa senang membuat siswa menjadi lebih aktif. Siswa aktif dalam mencari informasi, memahami materi yang dipelajari melalui buku pelajaran dan internet.

Rusman (2013:75) menyatakan bahwa kemampuan berpikir siswa pada pembelajaran berdasarkan masalah betulbetul dioptimalisasikan melalui proses kerja kelompok atau tim yang sistematis, sehingga siswa dapat memberdayakan, mengasah, menguji, dan mengembangkan kemampuan berpikirnya secara berkesinambungan. Namun dalam penelitian ini diperoleh bahwa hasil hasil belajar yang dipengaruhi oleh aktivitas per individu lebih besar daripada aktivitas per kelompoknya.

Berdasarkan hasil penelitian terdahulu yang dilakukan oleh Selcuk (2010:720) menyatakan bahwa mengajar ilmu fisika menggunakan model problem based learning jauh lebih efektif keberhasilannya daripada menggunakan pembelajaran konvensional. Selain itu, model problem based learning juga dapat meningkatkan hasil belajar secara berkelompok bukan hanya secara individu. Pembelajaran berdasarkan masalah merupakan teknik yang cukup bagus untuk lebih memahami isi pelajaran dan membantu siswa bagaimana mentransfer pengetahuan mereka untuk memahami masalah dalam kehidupan nyata. Namun, berdasarkan hasil penelitian yang diperoleh peneliti bahwa hasil belajar lebih dipengaruhi oleh aktivitas individu daripada aktivitas kelompoknya. Hal ini dapat disebabkan oleh kesalahan sintaks model PBL saat diterapkan pada kegiatan belajar mengajar.

Sembiring (2014:53) menyimpulkan bahwa ada perbedaan hasil belajar siswa menggunakan model pembelajaran berdasarkan masalah dengan pembelajaran konvensional, dimana ratarata hasil belajar siswa di kelas eksperimen yaitu 40,94 sedangkan kelas kontrol yaitu 27,50. Simarmata (2015:66) dengan hasil penelitian menyimpulkan bahwa pembelajaran fisika dengan menerapkan model pembelajaran berdasarkan masalah dapat meningkatkan hasil belajar siswa dan terjadi peningkatan aktivitas setiap pertemuan dengan nilai rata-rata siklus I sebesar 60,35, siklus II sebesar 68,28 dan siklus III sebesar 77,38. Siregar (2015:58) menyimpulkan ada peningkatan hasil belajar belajar dari rata-rata 64,38 menjadi 75,94 serta peningkatan aktivitas belajar pada pertemuan I sebesar $55 \%$, pertemuan 
II sebesar $72 \%$, dan pertemuan III sebesar $74 \%$.

Berdasarkan hasil penelitian yang dilakukan oleh Eldy and Sulaiman, (2013:24) menyatakan bahwa ada perbedaan yang signifikan antara hasil belajar serta keterampilan berpikir kreatif dan kritis mahasiswa yang yang menggunakan model problem based learning. Peran guru di kelas eksperimen yang menerapkan model problem based learning tidak hanya ceramah di dalam ruangan tetapi siswa langsung dihadapkan pada eksperimen yang mendukung teori tersebut, sehingga hal itu dapat membantu meningkatkan rasa percaya diri siswa dan menjadi aktif dalam pembelajaran dan keterampilan sosial siswa menjadi berkembang.

Terdapat beberapa kendala yang dihadapi selama pembelajaran. Salah satu kendala yang terjadi adalah ketika mengorganisasikan siswa dalam kelompok berupa penggunaan waktu yang cukup lama karena belum terbiasa sebelumnya serta pengaturan jumlah siswa dalam satu kelompok yang terlalu banyak. Rasa malu dan ragu dalam pengambilan kesimpulan masih tertanam pada diri siswa, sehingga siswa mengalami kesulitan dalam membuat kesimpulan hasil kerja kelompoknya. Peneliti juga mengalami kendala dalam mengawasi siswa dalam setiap kelompok karena observer yang dilibatkan terbatas.

Berdasarkan hasil penelitian yang dilakukan, terdapat perbedaan hasil belajar dan hasil observasi aktivitas antara kelas eksperimen dengan kelas kontrol. Hasil penelitian menunjukkan bahwa ada pengaruh yang signifikan model pembelajaran berdasarkan masalah terhadap hasil belajar siswa pada materi pokok kinematika gerak lurus di Kelas X Semester I SMA Negeri 1 Tanjung Morawa T.P. 2015/2016.

\section{KESIMPULAN DAN SARAN Kesimpulan}

Berdasarkan hasil penelitian yang diperoleh maka dapat disimpulkan bahwa hasil belajar siswa dengan menggunakan model pembelajaran berdasarkan masalah pada materi pokok kinematika gerak lurus memberikan nilai rata-rata dengan kategori baik. Hasil belajar siswa dengan menggunakan pembelajaran konvensional khususnya pada materi pokok kinematika gerak lurus memberikan nilai rata-rata dengan kategori cukup baik. Ada pengaruh model pembelajaran berdasarkan masalah terhadap hasil belajar siswa pada materi pokok kinematika gerak lurus di kelas $\mathrm{X}$ Semester I SMA Negeri 1 Tanjung Morawa T.P. 2015/2016.

Aktivitas siswa yang dikembangkan dari model pembelajaran berdasarkan masalah dapat meningkatkan keaktifan siswa dalam proses pembelajaran dengan kategori rata-rata aktivitas di setiap pertemuan dinyatakan aktif.

\section{Saran}

Sangat dibutuhkan pemahaman sintaks dan ciri-ciri model pembelajaran dalam menggunakan model pembelajaran berdasarkan masalah dengan benar sesuai tahapanya, sebagai salah satu upaya untuk membuat siswa lebih aktif dalam pembelajaran, menambah kreativitas, semangat belajar siswa, serta meningkatkan hasil belajar siswa.

Peneliti selanjutnya yang ingin meneliti tentang model pembelajaran berdasarkan masalah lebih lanjut, disarankan untuk lebih memperhatikan efisiensi waktu pada tahap "mengembangkan dan menyajikan hasil karya", karena pada tahap ini hampir semua siswa ingin menampilkan hasil diskusi mereka, pembagian kelompok serta penyediaan materi ajar untuk persiapan siswa.

\section{DAFTAR PUSTAKA}

Arends, R.I, (2012), Learning to Teach ninth edition: Belajar untuk mengajar, Pustaka Pelajar, Yogyakarta

Eldy, E., and Sulaiman, F., (2013), Integrated PBL Approach: Preliminary Findings towards Physics Students' Critical Thinking and Creative-Critical 
Thinking, International Journal of Humanities and Social Science Invention, Volume 2 Issue 3, pp.18-25

Rusman., (2013),

Model-Model Pembelajaran Mengembangkan Profesionalsme Guru Edisi Kedua, PT Gravindo Persada, Jakarta.

Rusnayati, H., (2011), Penerapan model pembelajaran problem based learning dengan pendekatan inkuiri untuk meningkatkan keterampilan proses sains dan penguasaan konsep elastisitas pada siswa SMA, Jurnal Prosiding Seminar Nasional Penelitian Fakultas MIPA UNY 2011.

Sanjaya, W., (2011), Strategi Pembelajaran Berorientasi Standar Proses Pendidikan, Kencana Prenada Media Group, Jakarta.

Santyasa, I Wayan, (2008), Pembelajaran Berbasis Masalah dan Pembelajaran Kooperatif, Universitas Pendidikan Ganesha, Nusa Penida.

Selcuk, G. S., (2010), The effects of problem-based learning on pre-service teachers' achievement, approaches and attitudes towards learning physics, International Journal of the Physical Sciences Vol. 5(6), pp. 711-723

Sembiring, S., (2014), Pengaruh Model PBL terhadap Hasil Belajar Siswa pada Materi Pokok Suhu dan Kalor di Kelas X Semester II SMAN 2 Kabanjahe T.P.2013/2014, Skripsi, FMIPA, Unimed, Medan

Simarmata, B., (2015), Pengaruh Model PBL terhadap Hasil Belajar Siswa pada Materi Pokok Suhu dan Kalor di Kelas X Semester II SMA Swasta Katolik Sibolga T.P.2014/2015, Skripsi, FMIPA, Unimed, Medan

Siregar, T., (2015), Pengaruh Model PBL terhadap Hasil Belajar Siswa pada Materi Pokok Listrik Dinamis di Kelas $X$ Semester II SMAN 1 Siantar Narumonda T.P.2014/2015, Skripsi, FMIPA, Unimed, Medan

Sugiyono, S. (2011). Prosedur Penelitian Suatu Pendekatan Praktik, Rineka Cipta, Jakarta 